\title{
PENGARUH PENGETAHUAN AKUNTANSI DAN PENGALAMAN USAHA TERHADAP PENGEMBANGAN USAHA DAN PENGGUNAAN INFORMASI AKUNTANSI SEBAGAI VARIABEL INTERVENING (Kajian Empiris Pada Pelaku Usaha Kecil dan Menengah di Kelurahan Tanjung Rejo Kecamatan Medan Sunggal)
}

\author{
Formaida Tambunan \\ formaidatambunans@yahoo.com \\ Universitas Sari Mutiara Indonesia
}

\begin{abstract}
This research aims to examine and analyze the influence of accounting knowledge and experience effort towards the development of a mediation effort with the use of accounting information on the perpetrators of the UKM. Research conducted in the village of Tanjung Rejo Medan Sunggal in 2019.This research is quantitative research associate. Population and sample of this research is 40 principals with UKM error rate of 5\%. Types and sources of data that dikumulkan is quantitative data and secondary data by analyzing the use test, test the normality assumption linieritas and using path analysis. The conclusions of the results of this study are: 1) influential accounting knowledge against the use of accounting information, whereas business experience has no effect against the use of accounting information accounting knowledge, 2) knowledge of accounting and business experience a positive effect towards enterprise development, and 3) accounting knowledge and business experience have indirect influence through the use of accounting information to the development effort.
\end{abstract}

Key Words: Business experience, accounting knowledge, use of accounting information and business development

\begin{abstract}
Abstrak
Penelitian ini bertujuan untuk menguji dan menganalisis pengaruh pengetahuan akuntansi dan pengalaman usaha terhadap pengembangan usaha dengan mediasi penggunaan informasi akuntansi pada pelaku UKM. Penelitian dilakukan di Kelurahan Tanjung Rejo Kecamatan Medan Sunggal pada tahun 2019. Penelitian ini merupakan penelitian kuantitatif asosiatif. Populasi dan sampel dari penelitian ini adalah 40 pelaku UKM dengan tingkat kesalahan $5 \%$. Jenis dan sumber data yang dikumulkan adalah data kuantitatif dan data sekunder dengan menganalisis menggunakan uji asumsi normalitas, uji linieritas dan menggunakan analisis jalur (path analysis). Hasil penelitian ini diperolehh : 1) Pengetahuan akuntansi berpengaruh terhadap penggunaan infomasi akuntansi, sedangkan pengalaman usaha tidak berpengaruh terhadap penggunaan informasi akuntansi,2)pengetahuan akuntansi dan pengalaman usaha berpengaruh positif terhadap pengembangan usaha, dan 3) pengetahuan akuntansi dan pengalaman usaha mempunyai pengaruh tidak langsung melalui penggunaan informasi akuntansi terhadap pengembangan usaha.
\end{abstract}


Kata Kunci : Pengetahuan akuntansi, pengalaman usaha, penggunaan informasi akuntansi, pengembangan usaha

\section{Pendahuluan}

Kegiatan usaha kecil, dan menengah (UKM) merupakan salah satu bidang usaha yang dapat berkembang dan konsisten dalam perekonomian nasional. UKM menjadi wadah yang baik bagi penciptaan lapangan pekerjaan yang produktif. Pengembangan dan pertumbuhan UKM merupakan salah satu motor penggerak yang krusial bagi pembangunan ekonomi. Berdasarkan pengalaman di negaranegara maju menunjukkan bahwa UKM adalah sumber dari inovasi produksi dan teknologi, pertumbuhan jumlah wirausahawan yang kreatif dan inovatif dan penciptaan tenaga kerja terampil dan fleksibel dalam proses produksi. ${ }^{1}$

Hal ini diperkuat dengan adanya kebijakan pemerintah dalam nawacita periode 2015-2019, yaitu mewujudkan UMKM yang berdaya saing dan berkontribusi pada peningkatan perekonomian nasional dan kesejahteraan rakyat berlandaskan semangat wirausaha, kemandirian dan keterpaduan, dimana akses untuk permodalan, pemerintah berupaya menurunkan bunga KUR (Kredit Usaha Rakyat) agar lebih terjangkau bagi UMKM.

Meskipun memiliki peran yang strategis, pengembangan UKM juga bukan merupakan hal yang mudah, peranan pemilik UKM sangat dibutuhkan untuk menghadapi tantangan perkembangan UKM sekarang ini. Dalam UKM biasanya pengusaha merupakan pemilik sekaligus pengelola usaha, oleh karena itu pengusaha mempunyai tanggung jawab penuh terhadap usaha yang dijalankan sehingga semua keputusan yang bersangkutan dengan perusahaan sepenuhnya berada ditangan mereka. Tentu saja hal ini menjadi tugas yang berat bagi seorang pemilik, jika mereka tidak memiliki keahlian untuk menyelesaikan sendiri masalah yang timbul dalam usahanya. ${ }^{2}$

Berdasarkan data Dinas Koperasi dan UMKM Kota Medan tahun 2017 mencapai angka 580 UMKM dimana $81 \%$ usaha mikro, 17\% usaha kecil dan 2\% merupakan usaha menengah dan hal ini terjadi penurunan pelaku UMKM di Kota Medan jika dibandingkan dengan data tahun 2013, berdasarkan Dinas Koperasi dan UMKM Kota Medan mencapai angka 2.847 UMKM. Terjadi penurunan UMKM selama 5 tahun sebanyak 2.267 UMKM atau $80 \%{ }^{3}$ 
Formaida Tambunan: Pengaruh Pengetahuan Akuntansi Dan Pengalaman |373

Perkembangan UMKM di kota Medan tidak berjalan seperti potensi yang diharapkan. Ada beberapa hal yang menjadi hambatan dalam pengembangan UKM di kota Medan. Seperti yang diungkapkan oleh Siropolis pada tahun 1994 bahwa 44\% kegagalan disebabkan oleh kurangnya kompetensi dalam dunia usaha, 17\% kegagalan karena lemahnya kemampuan manajemen, dan ketidakseimbangan pengalaman yang dimiliki oleh para pelaku usaha, serta pengendalian keuangan yang lemah dan administrasi yang kacau menjadi salah satu sebab utama gagalnya suatu usaha. ${ }^{4}$

Dengan permasalahan tersebut perlunya peningkatan daya saing bagi pelaku UKM di kota Medan. Peningkatan daya saing dalam pengembangan usaha memerlukan kemampuan untuk mengelola keuangan yang baik, salah satunya dengan memanfaatkan informasi akuntansi Dalam berbagai aktivitas usaha, informasi akuntansi dipandang potensial karena mampu memberikan kontribusi terhadap berbagai tindakan yang bisa dijadikan pertimbangan dalam perencanaan, pengawasan, pengendalian dan pengambilan keputusan, oleh karena itu para pengusaha kecil dan menengah dituntut untuk memiliki kemampuan menganalisis dan menggunakan data akuntansi. ${ }^{5}$

Informasi akuntansi merupakan bagian yang terpenting dari seluruh informasi yang diperlukan manajemen terutama yang berhubungan dengan data keuangan. ${ }^{6}$ Tujuan informasi akuntansi tersebut adalah memberikan petunjuk dalam memilih tindakan yang paling baik untuk mengalokasikan sumber daya yang langka pada aktivitas bisnis dan ekonomi. ${ }^{7}$

Hal ini terjadi dikarenakan kurangnya pemahaman akuntansi, dimana UKM masih banyak belum melakukan pencatatan atas laporan keuangannya yang baik. Kebanyakan UKM hanya mencatat jumlah uang yang diterima dan dikeluarkan, jumlah barang yang dibeli dan dijual, dan jumlah piutang/utang. ${ }^{8}$ Bahkan kondisi yang terjadi rata-rata pelaku UKM di Kota Medan adalah tamatan Sekolah Dasar maupun Sekolah Menengah Umum/Kejuruan sehingga adanya keterbatasan pendidikan terhadap pengetahuan akuntansi.

Setiap pelaku usaha tentu berbeda antara satu dan lainnya, baik itu mengenai latar belakang pendidikan, latar belakang keluarga dan lain sebagainya. Adapun faktor-faktor yang dapat mempengaruhi persepsi seorang pelaku usaha dari karakteristik pribadinya meliputi sikap, kepribadian, motivasi dan 
pengalaman. Semakin banyak dan baik pengalaman seorang pelaku usaha atas informasi akuntansi, maka akan semakin baik pula kemampuan seorang pelaku usaha dalam mengelola perusahaannya. Seorang pelaku usaha harus berani belajar dari pengalaman orang lain juga, belajar dari kegagalan maupun keberhasilan dimasa-masa yang lalu yaitu proses belajar dalam menunjang keberhasilan dalam pengembangan usaha. ${ }^{9}$

Melihat permasalahan tersebut di atas juga dialami oleh pihak UKM di Kota Medan, dimana seharusnya dunia usaha yang berkembang menuntut pelaku UKM untuk memiliki peranan dalam menentukan keberhasilan bisnisnya dengan menggunakan pengetahuan akuntansi dan pengalaman usaha dalam informasi akuntansi yang meliputi tujuh aspek antara lain, yaitu: a) peningkatan modal, b) peningkatan jumlah produksi, c) jumlah pelanggan, d) perluasan usaha, e) perluasan daerah pemasaran, f) perbaikan sarana fisik dan g) peningkatan pendapatan usaha yang optimal(Dwidah dan Laturette, 2016). Oleh karena itu, untuk dapat mendorong pengusaha kecil menyelenggarakan dan menggunakan informasi akuntansi tergantung dari persepsi pelaku usaha UKM yang dipengaruhi oleh faktor-faktor proses belajar, motivasi, pengalaman usaha dan kepribadian. Persepsi ini selanjutnya akan berpengaruh terhadap sikap dan perilaku sehari-hari yang tercermin dalam menjalankan usahanya sehingga pada akhirnya dapat mempengaruhi keberhasilan usahanya yang dapat mewujudkan pengembangan usaha.

Berdasarkan riset pendahuluan pada 15 UKM di Kelurahan Tanjung Rejo Kecamatan Medan Sunggal dimana pelaku usaha kecil dan menengah yang menekuni usaha lebih dari 3 (tiga) tahun masih ditemukan belum menggunakan informasi akuntansi sebagai pendukung pengambilan keputusan bisnis untuk pengembangan usaha dikarenakan pemahaman pengetahuan akuntansi masih sebatas keputusan arus kas saja. Melalui penelitian yang dilakukan Sunaryanto menyatakan bahwa lamanya seorang pelaku usaha menekuni usahanya maka akan meningkat pula pengetahuannya dan akan berpengaruh pada tingkat pendapatannya. Dengan kata lain, semakin lama seorang pelaku bisnis menjalankan usahanya maka akan semakin meningkat pula pengetahuan mengenai perilaku konsumen dan informasi akuntansi ${ }^{10}$. 
Formaida Tambunan: Pengaruh Pengetahuan Akuntansi Dan Pengalaman |375

Pelaku UKM di Kelurahan Tanjung Rejo Kecamatan Medan Sunggal hanya melakukan pencatatan uang masuk dan keluar, pencatatan pembelian barang, pencatatan utang dan piutang, jika ada laporan keuangan hanya digunakan untuk memenuhi pelaporan perpajakan saja. Dan berdasarkan riset pendahuluan dari ke-15 UKM tersebut, dengan karakteristik jenis kelamin, pendidikan dan lama usaha yakni laki-laki $80 \%$ dan perempuan 20\%, dengan pendidikan SMA/SMK 70\%, D3 5\% dan S1 25\%. Lama Usaha $<5$ tahun 8\%, 6-10 tahun 50\% dan lebih dari 10 tahun $22 \%$.

Melihat kondisi-kondisi yang terjadi, peneliti memandang perlu mengangkat hal tersebut kedalam suatu penelitian yang berjudul "Pengaruh Pengetahuan Akuntansi dan Pengalaman Usaha Terhadap Pengembangan Usaha dan Penggunaan Informasi Akuntansi sebagai variabel intervening (Kajian Empiris Pada Pelaku Usaha Kecil dan Menengah di Kelurahan Tanjung Rejo Kecamatan Medan Sunggal)

\section{Pengetahuan Akuntansi}

Pengetahuan akuntansi diartikan sebagai pengetahuan keakuntansian yang dimiliki pengusaha kecil dan menengah. Akuntansi merupakan suatu proses pencatatan, penggolongan, peringkasan, pelaporan dan penganalisaan data keuangan suatu organisasi. ${ }^{11}$ Menurut Jusup, proses belajar mengenai akuntansi akan meningkatkan pengetahuan akuntansi pengusaha (manajer) sehingga pemahaman pengusaha (manajer) untuk menerapkan informasi akuntansi juga akan semakin meningkat. ${ }^{12}$

Manfaat pengetahuan akuntansi bagi perusahaan yaitu :

a. Mengetahui besarnya modal yang dimiliki perusahaan.

b. Mengetahui perkembangan atau maju mundurnya perusahaan.

c. Sebagai dasar untuk penghitungan pajak.

d. Menjelaskan keadaan perusahaan sewaktu-waktu memerlukan kredit bank atau pihak lain.

e. Dasar untuk menentukan kebijakan yang akan ditempuh.

f. Menarik minat investor saham jika perusahaan berbentuk perseroan terbatas. $^{13}$ 
Pengetahuan akuntansi pemilik dapat tercermin melalui perlakuan pemilik usaha atau manajer dalam mengelola keuangan perusahaan. Dengan kata lain praktik akuntansi dalam suatu perusahaan mencerminkan tingkat pengetahuan akuntansi pemilik. Pengetahuan akuntansi dapat di identifikasi dari pengalaman pemilik usaha atau manajer pada partisipasinya dalam program pelatihan akuntansi yang pernah diikuti. Semakin baik pengetahuan akuntansi yang dimiliki oleh pemilik usaha atau manajer, maka semakin baik pula kemampuan mereka dalam menggunakan informasi akuntansi. ${ }^{14}$

\section{Pengembangan Usaha}

Pengembangan usaha adalah tanggung jawab dari setiap pengusaha atau wirausaha yang membutuhkan pandangan kedepan, motivasi dan kreativitas. ${ }^{15}$ Usaha adalah melakukan kegiatan secata tetap dan terus-menerus dengan tujuan memperoleh keuntungan, baik yang diselenggarakan oleh perorangan maupun badan usaha yang berbentuk badan hukum atau tidak badan hukum, yang didirikan dan berkedudukan di suatu daerah dalam suatu negara. ${ }^{16}$

\section{Informasi Akuntansi}

Informasi akuntansi merupakan suatu pembelajaran yang diperoleh pengusaha dalam menjalankan usahanya. Penyelenggaraan informasi akuntansi adalah pencatatan kegiatan-kegiatan usaha/transaksi kedalam catatan-catatan akuntansi, sedangkan penggunaan informasi akuntansi adalah pemanfaatan informasi-informasi akuntansi untuk pengambilan keputusan bisnis. ${ }^{17}$

\section{Metode Penelitian}

Populasi dalam penelitian ini adalah pelaku UKM di Kelurahan Tanjung Rejo Kecamatan Medan Sunggaldengan total populasi sebanyak 40 UKM. Teknik sampel yang digunakan adalah sampel jenuh. Sampel jenuh adalah teknik penentuan sampel bila semua anggota populasi digunakan sebagai sampel. Istilah lain dari sampel jenuh adalah sensus sehingga sampel dalam penelitian ini sebanyak 40 UKM.Analisis data yang digunakan dalam penelitian ini adalah analisis jalur. Model analisis jalur bertujuan untuk mengetahui pengaruh variabel independen terhadap variabel dependen baik secara langsung maupun tidak langsung. Model analisis jalur didapatkan persamaan tiga kali pengujian regresi yaitu: 
Formaida Tambunan: Pengaruh Pengetahuan Akuntansi Dan Pengalaman |377

1) Sub Struktural 1

Pengaruh pengetahuan akuntansi dan pengalaman usaha ke penggunaan informasi akuntansi: $Z=a+\beta 1 X 1+\beta 2 X 2$

2) Sub Struktural 2

Pengaruh pengetahuan akuntansi dan pengalaman usaha ke pengembangan usaha: $\mathrm{Y}=\mathrm{a}+\beta 1 \mathrm{X}+\beta 2 \mathrm{X} 2$

3) Sub Struktural 3

Pengaruh penggunaan informasi akuntansi ke pengembangan usaha : $\mathrm{Y}=\mathrm{a}+$ $\beta 3 Z$

Keterangan:

$\mathrm{Y}=$ Variabel dependen (Pengembangan Usaha)

$\mathrm{X} 1=$ Variabel Pengetahuan Akuntansi

$\mathrm{X} 2$ = Variabel Pengalaman Usaha

$\mathrm{Z}=$ Variabel intervening (Penggunaan Informasi Akuntansi)

$\mathrm{B} 1,2=$ Koefisien regresi

$\mathrm{a} \quad=$ Koefisien konstanta

Beberapa asumsi klasik regresi yang harus dipenuhi terlebih dahulu sebelum menggunakan analisis regresi sebagai alat untuk menganalisis pengaruh variabel-variabel yang diteliti yaitu: uji normalitas, uji linieritas.

\section{Hasil Penelitian}

Pengujian hipotesis untuk menjawab tujuan penelitian dilakukan tiga kali tahapan analisis regresi dengan uraian sebagai berikut:

a. Analisis Regresi Jalur 1.

Tabel 1

\begin{tabular}{|c|c|c|c|c|c|}
\hline \multicolumn{6}{|l|}{ Coefficients $^{\mathrm{a}}$} \\
\hline \multirow[b]{2}{*}{ Model } & \multicolumn{2}{|c|}{$\begin{array}{l}\text { Unstandardized } \\
\text { Coefficients }\end{array}$} & \multirow{2}{*}{\begin{tabular}{|l} 
Standardized \\
Coefficients
\end{tabular}} & \multirow[b]{2}{*}{$\mathrm{t}$} & \multirow[b]{2}{*}{ Sig. } \\
\hline & B & Std. Error & & & \\
\hline (Constant) & 10.805 & 3.854 & & 2.804 & .008 \\
\hline Pengetahuan Akuntansi & .325 & .155 & .363 & 2.093 & .043 \\
\hline Pengalaman Usaha & .416 & .239 & .301 & 1.738 & .090 \\
\hline
\end{tabular}

a. Dependent Variable: Penggunaan Informasi Akuntansi 


\section{1) Persamaan Sub Struktural 1}

Dari tabel di atas dapat diketahui nilai konstanta $=10,805$, koefisien regresi pengetahuan akuntansi $=0,363$ dinyatakan sebagai $\mathrm{P} 1$ dan koefisien regresi pengalaman usaha $=0,301$ dinyatakan sebagai $\mathrm{P} 2$ sehingga diperoleh persamaan sub struktural 1 adalah:

Penggunaan Informasi Akuntasi $=10,805+0,363$ pengetahuan akuntansi $+0,301$ pengalaman usaha $+\mathrm{e} 1$.

\section{2) Uji Hipotesis Jalur 1}

Uji hipotesis pada sub struktural 1 ini terdiri dari uji $\mathrm{t}$ dan uji $\mathrm{F}$ untuk menjawab tujuan penelitian dan hipotesis yang diajukan.

\section{a) Uji t}

Uji t pada sub struktural bertujuan untuk menganalisis pengaruh variabel pengetahuan akuntansi (X1)dan pengalaman usaha (X2)secara parsial terhadap penggunaan informasi akuntansi (Z). Berdasarkan tabel diketahui variabel pengetahuan akuntansi dengan nilai $\mathrm{t}_{\text {hitung }}=2,093$ pada taraf $\alpha=5 \%(0,05)$ dengan $\mathrm{df}=\mathrm{n}-\mathrm{k}=40-$ $3=37$ sehingga diketahui ttabel $=2,026$ dimana hasil menunjukkan $t_{\text {hitung }}>t_{\text {tabel }}$, Ha diterima dan H0 ditolak yang artinya pengetahuan akuntansi berpengaruh secara parsial terhadap penggunaan informasi akuntansi pada pelaku UKM.

Selanjutnya berdasarkan tabel diketahui variabel pengalaman usaha dengan nilai $t_{\text {hitung }}=1,738$ pada taraf $\alpha=5 \%(0,05)$ dengan $\mathrm{df}$ $=\mathrm{n}-\mathrm{k}=40-3=37$ sehingga diketahui $\mathrm{t}_{\text {tabel }}=2,026$ dimana hasil menunjukkan $t_{\text {hitung }}<t_{\text {tabel }}$, H0 diterima dan Ha ditolak yang artinya pengalaman usaha tidak berpengaruh secara parsial terhadap penggunaan informasi akuntansi pada pelaku UKM.

b) Uji F

Uji $F$ pada sub struktural 2 bertujuan untuk menganalisis pengaruh pengalaman usaha (X1) dan pengetahuan akuntansi (X2) secara simultan terhadap penggunaan informasi akuntansi (Z). Berdasarkan hasil pengolahan data diperoleh ringkasan pada tabel berikut ini:

\section{Tabel 2 Uji F}


Formaida Tambunan: Pengaruh Pengetahuan Akuntansi Dan Pengalaman |379

\begin{tabular}{|c|c|c|c|c|c|c|}
\hline \multicolumn{2}{|c|}{ Model } & Sum of Squares & $\mathrm{df}$ & Mean Square & $\mathrm{F}$ & Sig. \\
\hline 1 & Regression & 785.357 & 2 & 392.679 & 10.629 & $.000^{\mathrm{a}}$ \\
\hline & Residual & 1366.914 & 37 & 36.944 & & \\
\hline & Total & 2152.271 & 39 & & & \\
\hline
\end{tabular}

Dari tabel di atas diketahui nilai $\mathrm{F}_{\text {hitung }}=10,629$ dengan taraf $\alpha=5 \%$ dimana $\mathrm{df}=\mathrm{n}-\mathrm{k}=40-3=37$ sehingga diketahui $\mathrm{F}_{\text {tabel }}=$ 3,25 dimana hasil menunjukkan $\mathrm{F}_{\text {hitung }}>\mathrm{F}_{\text {tabel }}$, Ha diterima dan $\mathrm{H} 0$ ditolak yang artinya pengetahuan akuntansi dan pengalaman usaha berpengaruh secara simultan terhadap penggunaan informasi akuntansi pada pelaku UKM.

c) Koefisien Determinasi Jalur 1

Koefisien determinasi bertujuan untuk menganalisis besar pengaruhnya pengetahuan akuntansi dan pengalaman usaha terhadap penggunaan informasi akuntansi. Berdasarkan hasil pengolahan data diperoleh ringkasan pada tabel berikut ini:

\section{Tabel 3 Hasil Koefisien Determinasi Jalur 1}

Model Summary

\begin{tabular}{|r|l|l|l|l|}
\hline Model & $R$ & R Square & Adjusted R Square & Std. Error of the Estimate \\
\hline 1 & $604^{\mathrm{a}}$ & 365 & 331 & 6.078126 \\
\hline
\end{tabular}

a. Predictors: (Constant), Pengetahuan Akuntansi, Pengalaman Usaha

Dari tabel di atas diketahui nilai $\mathrm{R}=0,604$ sehingga koefisien determinasi $(\mathrm{KD})$ adalah $\mathrm{KD}=\mathrm{r}^{2} * 100 \%=0,604 * 100 \%=60,4 \%$ yang artinya adalah penggunaan informasi akuntansi dapat dijelaskan oleh pengetahuan akuntansi dan pengalaman usaha sebesar $60,4 \%$ dan sisanya 39,6\% dijelaskan oleh faktor lain di luar model.

\section{b. Analisis Regresi Jalur 2}

Analisis regresi 2 ini bertujuan untuk menganailis pengaruh pengetahuan akuntansi dan pengalaman usaha terhadap pengembangan usaha. Koefisien determinasi $\left(\mathrm{R}^{2}\right)$ pada intinya mengukur seberapa jauh kemampuan sebuah model menerangkan variasi variabel dependen. Nilai koefisien 
determinasi adalah antara nol dan satu. Nilai $\mathrm{R}^{2}$ yang kecil berarti kemampuan variabel-variabel independen dalam menjelaskan variabel dependen sangat terbatas. Nilai yang mendekati satu berarti variabel-variabel independen memberikan hampir semua informasi yang dibutuhkan untuk memprediksi variasi variabel dependen.

Berdasarkan hasil pengolahan data diperoleh ringkasan pada tabel berikut ini:

Tabel 4 Hasil Uji Regresi Jalur 2

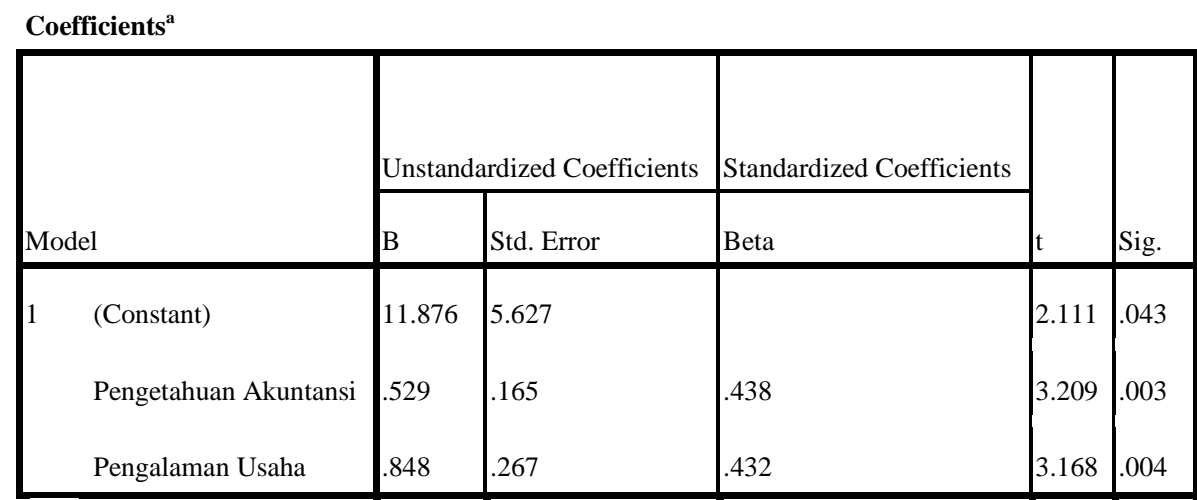

a. Dependent Variable: Pengembangan Usaha

\section{1) Persamaan Sub Struktural 2}

Berdasarkan hasil pengolahan data pada tabel 4.9 di atas dapat diketahui nilai konstanta $=11,876$, koefisien regresi pengalaman usaha $=0,432$ dinyatakan sebagai $\mathrm{P} 3$, koefisien regresi pengetahuan akuntansi $=0,438$ dinyatakan sebagai P4 sehingga diperoleh persamaan sub struktural 2 adalah: Pengembangan Usaha $=11,876+0,438$ pengetahuan akuntansi + 0,432 pengalaman usaha $+\mathrm{e} 2$

\section{2) Uji Hipotesis Jalur 2}

Uji signifikansi pada sub struktural 2 ini terdiri dari uji t dan uji $F$ untuk menjawab tujuan penelitian dan hipotesis yang diajukan.

a) Uji t

Uji t bertujuan untuk menganalisis pengaruh variabel pengetahuan akuntansi (X1)pengalaman usaha (X2), dan penggunaan informasi 
Formaida Tambunan: Pengaruh Pengetahuan Akuntansi Dan Pengalaman |381

akuntansi (Z) secara parsial dan simultan terhadap pengembangan usaha (Y).

Berdasarkan tabel diketahui pada variabel variabel pengetahuan akuntansi dengan nilai $t_{\text {hitung }}=3,209$, variabel pengalaman usaha dengan nilai $t_{\text {hitung }}=3,168$, pada taraf $\alpha=5 \%($ $0,05)$ dengan $\mathrm{df}=\mathrm{n}-\mathrm{k}=40-3=37$ sehingga diketahui $\mathrm{t}_{\text {tabel }}=$ 2,026 dimana hasil menunjukkan $t_{\text {hitung }}>t_{\text {tabel }}$, Ha diterima dan H0 ditolak yang artinya pengetahuan akuntansi dan pengalaman usaha secara parsial berpengaruh terhadap pengembangan usaha pada pelaku UKM.

b) Uji F

Uji $F$ bertujuan untuk menganalisis pengaruh pengalaman usaha (X1) pengetahuan akuntansi (X2) dan penggunaan informasi akuntansi (Z) secara simultan terhadap pengembangan usaha (Y). Berdasarkan pengolahan data diperoleh hasil berikut ini:

Tabel 5 Hasil Uji F Jalur 2

\begin{tabular}{|c|c|c|c|c|c|}
\hline Model & Sum of Squares & df & Mean Square & $\mathrm{F}$ & Sig. \\
\hline Regression & 1358.524 & 2 & 679.262 & 14.838 & $.000^{\mathrm{a}}$ \\
\hline Residual & 1373.348 & 30 & 45.778 & & \\
\hline Total & 2731.872 & 32 & & & \\
\hline
\end{tabular}

a. Predictors: (Constant), Pengetahuan Akuntansi, Pengalaman Usaha

b. Dependent Variable: Pengembangan Usaha

Dari tabel di atas diketahui nilai $F_{\text {hitung }}=14,838$ pada taraf $\alpha$ $=5 \%(0,05)$ dengan df $1=\mathrm{k}-1=4-1=3$, df $2=\mathrm{n}-\mathrm{k}=40-3=$ 37 sehingga diketahui $\mathrm{F}_{\text {tabel }}=2,86$ dimana hasil menunjukkan $\mathrm{F}_{\text {hitung }}>$ $\mathrm{F}_{\text {tabel}}$, Ha diterima dan $\mathrm{H} 0$ ditolak yang artinya pengetahuan akuntansi dan pengalaman usaha secara simultan berpengaruh terhadap pengembangan usaha pada pelaku UKM.

c. Analisis Regresi 3

Analisis regresi 3 ini bertujuan untuk menganailis pengaruh penggunaan informasi akuntansi terhadap pengembangan usaha. Koefisien determinasi $\left(\mathrm{R}^{2}\right)$ pada intinya mengukur seberapa jauh kemampuan sebuah model 
menerangkan variasi variabel dependen. Berdasarkan hasil pengolahan data diperoleh ringkasan pada tabel berikut ini:

Tabel 5 Hasil Uji Regresi Jalur 3

Coefficients $^{\mathrm{a}}$

\begin{tabular}{|c|c|c|c|c|c|}
\hline \multirow[b]{2}{*}{ Model } & \multicolumn{2}{|c|}{$\begin{array}{l}\text { Unstandardized } \\
\text { Coefficients }\end{array}$} & \multirow{2}{*}{\begin{tabular}{|l} 
Standardized Coefficients \\
Beta
\end{tabular}} & \multirow[b]{2}{*}{$\mathrm{t}$} & \multirow[b]{2}{*}{ Sig. } \\
\hline & B & Std. Error & & & \\
\hline (Constant) & 18.301 & 5.180 & & 3.533 & .001 \\
\hline Penggunaan Informasi Akuntansi & .868 & .185 & .644 & 4.684 & .000 \\
\hline
\end{tabular}

1) Persamaan Sub Struktural 2

Berdasarkan hasil pengolahan data pada tabel di atas dapat diketahui nilai konstanta $=18,301$, koefisien regresi penggunaan informasi akuntansi $=$ 0,644 dinyatakan sebagai P3 sehingga diperoleh persamaan sub struktural 3 adalah: Pengembangan Usaha $=18,301+0,644$ penggunaan informasi akuntansi.

2) Uji Hipotesis Jalur 3

Uji signifikansi pada sub struktural 3 ini adalah uji t untuk menjawab tujuan penelitian dan hipotesis yang diajukan.

a) Uji t

Uji t bertujuan untuk menganalisis pengaruh variabel penggunaan informasi akuntansi (Z) secara parsial terhadap pengembangan usaha (Y).

Berdasarkan tabel diketahui pada variabel penggunaan informasi akuntansi dengan nilai thitung $=4,684$ pada taraf $\alpha=5 \%(0,05)$ dengan $\mathrm{df}=\mathrm{n}-\mathrm{k}=40-3=37$ sehingga diketahui $\mathrm{t}_{\text {tabel }}=2,026$ dimana hasil menunjukkan thitung > ttabel, Ha diterima dan H0 ditolak yang artinya pengalaman usaha, pengetahuan akuntansi dan penggunaan informasi akuntansi secara parsial berpengaruh terhadap pengembangan usaha pada pelaku UKM.

b) Koefisien Determinasi Jalur 3 
Formaida Tambunan: Pengaruh Pengetahuan Akuntansi Dan Pengalaman |383 Koefisien determinasi bertujuan untuk menganalisis besar pengaruhnya pengalaman usaha dan pengetahuan akuntansi terhadap pengembangan usaha. Besarnya pengaruh dengan melihat hasil dari nilai Adjusted $R$ Square. Hasil koefisien determinasi jalur 3 dapat diringkas pada tabel berikut ini.

Tabel 6 Hasil Koefisien Determinasi Jalur 3

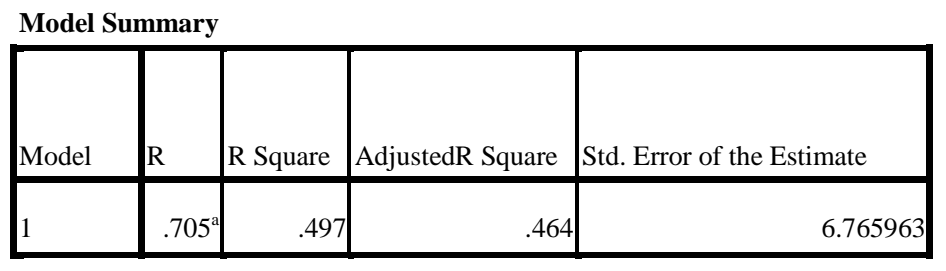

a. Predictors: (Constant), Pengetahuan Akuntansi, Pengalaman Usaha

Dari tabel di atas diketahui nilai Adjusted $R$ Square $=0,464$ sehingga koefisien determinasi $(\mathrm{KD})=0,464 * 100 \%=46,4 \%$ yang artinya pengembangan usaha pada pelaku UKM dapat dijelaskan oleh pengalaman usaha dan pengetahuan akuntansi sebesar 46,4\% dan sisanya 53,6\% dijelaskan oleh faktor lain di luar model.

\section{Analisis Jalur}

Pengujian penelitian ini menggunakan analisis jalur (path analysis). Analisis jalur merupakan perluasan dari analisis regresi linier berganda. Analisis regersi dilakukan sebanyak dua kali. Analisis regresi yang pertama untuk mengetahui kekuatan hubungan dari variabel bebas (independen) terhadap variabel mediasi (intervening). Analisis regresi yang kedua untuk mengetahui kekuatan hubungan dari variabel bebas (indenpenden) terhadap variabel terikat (dependen).

1) Pengaruh Pengetahuan Akuntansi Terhadap Pengembangan Usaha

a) Pengaruh Langsung $(\mathrm{P} 2)=0,438$

$$
=(0,438 \times 0,438) \times 100 \%=19,2 \%
$$

b) Pengaruh Tidak Langsung Melalui Penggunaan Informasi Akuntasi

$$
\begin{aligned}
& =\mathrm{P} 5 * \mathrm{P} 3 \\
& =0,363 * 0,644 \\
& =0,234
\end{aligned}
$$


c) Pengaruh Total Pengetahuan Akuntansi Terhadap Pengembangan Usaha

$=0,438+0,234$

$=0,672$

2) Pengaruh Pengalaman Usaha Terhadap Pengembangan Usaha

a) Pengaruh Langsung $(\mathrm{P} 1)=0,432$

b) Besarnya pengaruh langsung

$=\rho \mathrm{X} 1 \mathrm{Y} * \rho \mathrm{X} 1 \mathrm{Y}$

$=(0,432 \times 0,432) \times 100 \%$

$=18,7 \%$

c) Pengaruh Tidak Langsung Melalui Penggunaan Informasi Akuntasi

$=\mathrm{P} 4 \times \mathrm{P} 3$

$=0,301 \times 0,644$

$=0,194$

d) Pengaruh Total Pengalaman Usaha Terhadap Pengembangan Usaha

$=0,432+0,194$

$=0,626$

\section{Pembahasan}

\section{Pengaruh Pengetahuan Akuntansi dan Pengalaman Usaha Terhadap Penggunaan Informasi Akuntansi Pada Pelaku UKM}

Dari hasil uji statistik antara pengetahuan akuntansi dengan penggunaan informasi akuntansi pada pelaku UKM diperoleh nilai $\mathrm{t}_{\text {hitung }}=2,093>\mathrm{t}_{\text {tabel }}=$ 2,026, yang menunjukkan bahwa pengetahuan akuntansi berpengaruh terhadap penggunaan informasi akuntansi. Berdasarkan data yang diperoleh melalui kuesioner pengetahuan akuntansi diketahui 50\% menyatakan tidak setuju sebagai seorang pemilik atau manajer, responden mengetahui apa yang dimaksud dengan laporan laba rugi serta 50\% menyatakan tidak setuju sebagai seorang pemilik atau manajer, mengetahui apa yang dimaksud dengan arus kas. Hal ini menunjukkan bahwa ada 20 pelaku UKM dengan pengetahuan yang rendah tentang laporan rugi dan arus kas. Pengetahuan merupakan persepsi yang jelas akan apa yang dipandang sebagai fakta, kebenaran atau kewajiban, informasi dan atau pelajaran yang dipelihara dan diteruskan oleh peradaban. Pengetahuan akuntansi sebagai 
Formaida Tambunan: Pengaruh Pengetahuan Akuntansi Dan Pengalaman |385

suatu persepsi jelas akan apa yang dipandang sebagai fakta, kebenaran atau informasi mengenai proses pencatatan, pengelompokkan dan pengikthsaran kejadian-kejadian ekonomi dalam bentuk yang teratur dan logis dengan tujuan menyajikan informasi keuangan yang dibutuhkan untuk pengambilan keputusan.

Dari hasil yang diperoleh serta penjelasan di atas dapat diketahui bahwa pengetahuan akuntansi yang dimiliki pelaku UKM dapat dijadikan dasar dalam menggunakan informasi akuntansi untuk pengambilan keputusan. Keputusan yang diambil tersebut didasarkan dari setiap kegiatan usaha yang dijalankan seperti apakah di dalam usaha tersebut ada kemajuan ataupun kemunduran.

Selanjutnya berdasarkan hasil uji statistik antara pengalaman usaha dengan penggunaan informasi akuntansi pada pelaku UKM diperoleh nilai $t_{\text {hitung }}=1,738<$ $\mathrm{t}_{\text {tabel }}=2,026$, yang menunjukkan bahwa pengalaman usaha tidak berpengaruh terhadap penggunaan informasi akuntansi.

Dari data yang diperoleh melalui kuesioner pengalaman usaha menunjukkan 37,5\% menyatakan tidak setuju lama usaha membantu responden mengurangi kesalahan yang dilakukan dalam berwirausaha. Hasil ini menunjukkan bahwa pelaku UKM tidak belajar dari pengalaman usahanya untuk menghindari dari setiap kesalahan dalam menjalankan wirausahanya sehingga mengindikasikan pula bahwa pelaku UKM tidak memiliki pandangan ke depan dalam mengembangkan usaha yang dijalankan, namun sebaliknya diketahui ada 22,\% pelaku UKM setuju bahwa lama usaha membantu responden mengurangi kesalahan yang dilakukan dalam berwirausaha dimana hal ini menunjukkan bahwa setiap pelaku UKM belajar dari pengalaman usaha yang dijalankan untuk mencari cara mengembangkan usahanya. Hal ini diperkuat dari data pengembangan usaha menunjukkan $57,5 \%$ responden menyatakan tidak setuju memiliki rencana anggaran dalam pengambilan keputusan bisnis. Hasil ini mengindikasikan bahwa pelaku UKM tidak memiliki rencana di dalam menjalankan usaha sementara itu $15 \%$ menyatakan setuju dan 5\% menyatakan sangat setuju yang mengindikasikan sebaliknya bahwa pelaku UKM memiliki rencana di dalam menjalankan usaha.

Hasil penelitian ini sesuai dengan pendapat Nicholls dan Holmes (1989) yang menyatakan bahwa pengalaman dalam operasional berusaha atau lamanya perusahan beroperasi berdasarkan pada bisnis yang sudah dijalankan akan 
mengindikasikan kebutuhan akan informasi akuntansi sangat diperlukan (dalam Fitriyah, 2006). ${ }^{18}$ Holmes dan Nicholls (1989) yang dikutip Setyaningrum, dkk (2013) mengemukakan bahwa penggunaan informasi akuntansi dipengaruhi oleh usia usaha (lamanya suatu usaha berdiri mulai dari awal beroperasi hingga saat ini). Studi tersebut menyatakan bahwa semakin muda usia perusahaan terdapat kecenderungan untuk menyatakan informasi akuntansi yang ekstensif untuk tujuan membuat keputusan apabila dibandingan dengan perusahaan yang lebih tua usianya, sehingga perusahaan yang semakin muda usianya cenderung menggunakan informasi akuntansi dengan lebih optimal guna mencapai tujuannya tersebut.

Kemudian dari hasil uji statistik antara pengetahuan akuntansi dan pengalaman usaha dengan penggunaan informasi akuntansi pada pelaku UKM diperoleh nilai $\mathrm{F}_{\text {hitung }}=10,629>\mathrm{F}_{\text {tabel }}=3,32$ yang menunjukkan pengetahuan akuntansi dan pengalaman usaha berpengaruh terhadap penggunaan informasi akuntansi.

Dari hasil pengolahan data antara pengetahuan akuntansi dan pengalaman usaha dengan penggunaan informasi akuntansi menunjukkan bahwa setiap pelaku UKM yang memiliki pengalaman usaha atau telah lama menjalankan usahanya dapat mengetahui kendala-kendala yang diperoleh untuk mengatasi permasalahan yang dihadapi dengan mencari berbagai informasi sehingga dapat dijadikan sebagai dasar pengetahuan. Disisi lain bahwa pengetahuan akuntansi pemilik dapat tercermin melalui perlakuan pemilik usaha atau manajer dalam mengelola keuangan perusahaan. Dengan kata lain praktik akuntansi dalam suatu perusahaan mencerminkan tingkat pengetahuan akuntansi pemilik. Pengetahuan akuntansi dapat diidentifikasi dari pengalaman pemilik usaha atau manajer pada partisipasinya dalam program pelatihan akuntansi yang pernah diikuti. Semakin baik pengetahuan akuntansi yang dimiliki oleh pemilik usaha atau manajer, maka semakin baik pula kemampuan mereka dalam menggunakan informasi akuntansi (Setyaningrum, dkk, 2014).

Berdasarkan uraian di atas dapat disimpulkan bahwa pengetahuan akuntansi dan pengalaman usaha berpengaruh terhadap penggunaan informasi akuntansi pada pelaku UKM. 
Formaida Tambunan: Pengaruh Pengetahuan Akuntansi Dan Pengalaman |387

\section{Pengaruh Pengetahuan Akuntansi, Pengalaman Usaha dan Penggunaan Informasi Akuntansi Pada Pelaku UKM Terhadap Pengembangan Usaha}

Dari hasil uji statistik antara pengetahuan akuntansi dengan pengembangan usaha diperoleh nilai $t_{\text {hitung }}=3,209>t_{\text {tabel }}=2,026$, yang menunjukkan bahwa pengetahuan akuntansi berpengaruh terhadap pengembangan usaha pada pelaku UKM. Hasil penelitian ini dapat ditinjau dari pendapat Setyaningrum, dkk (2014) yang mengemukakan bahwa pengetahuan akuntansi pemilik dapat tercermin melalui perlakuan pemilik usaha atau manajer dalam mengelola keuangan perusahaan. Dengan kata lain praktik akuntansi dalam suatu perusahaan mencerminkan tingkat pengetahuan akuntansi pemilik. Pengetahuan akuntansi dapat diidentifikasi dari pengalaman pemilik usaha atau manajer pada partisipasinya dalam program pelatihan akuntansi yang pernah diikuti. Semakin baik pengetahuan akuntansi yang dimiliki oleh pemilik usaha atau manajer, maka semakin baik pula kemampuan mereka dalam menggunakan informasi akuntansi.

Pendapat di atas dapat terlihat dari hasil yang didapat dari kuesioner pengetahuan akuntansi diketahui bahwa masing-masing 12,5\% pelaku UKM mengetahui sebagai seorang pemilik atau manajer, mengetahui apa yang dimaksud dengan neraca dan mengetahui mengetahui apa yang dimaksud dengan laporan laba rugi. Hasil ini menunjukkan bahwa pengetahuan merupakan persepsi yang jelas akan apa yang dipandang sebaga fakta, kebenaran atau kewajiban, informasi dan atau pelajaran yang dipelihara dan diteruskan oleh peradaban. Dari definisi diatas dapat didefinisikan pengetahuan akuntansi sebagai suatu persepsi jelas akan apa yang dipandang sebagai fakta, kebenaran, atau informasi mengenai proses pencatatan, pengelompokan, dan pengikthsaran kejadian-kejadian ekonomi dalam bentuk yang teratur dan logis dengan tujuan menyajikan informasi keuangan yang dibutuhkan untuk pengambilan keputusan.

Selanjutnya darhasil uji statistik antara pengalaman usaha dengan pengembangan usaha diperoleh nilai $t_{\text {hitung }}=3,168>t_{\text {tabel }}=2,026$, yang menunjukkan bahwa pengalaman usaha berpengaruh terhadap pengembangan usaha pada pelaku UKM. 
Berdasarkan data yang diperoleh melalui kuesioner pengalaman usaha diketahui 37,5\% menyatakan tidak setuju pengalaman usaha mempunyai pengaruh menggunakan laporan keuangan untuk keputusan bisnis, namun sebaliknya diketahui $22,5 \%$ setuju dan $2,5 \%$ yang menyatakan sangat setuju bahwa pengalaman usaha mempunyai pengaruh menggunakan laporan keuangan untuk keputusan bisnis. Hasil ini menunjukkan bahwa pengalaman usaha dari pelaku UKM memberikan dampak positif dalam mengembangkan usaha yang dijalankan. Pengalaman usaha ini dapat diantaranya adalah keuntungan yang diperoleh setiap bulannya ataupun setiap tahunnya. Pengalaman usaha dapat dijadikan pembelajaran bagi pelaku UKM untuk mengambil suatu keputusan dalam mengembangkan usaha yang dijalankannya.

Hasil ini sejalan dengan pendapat Staw (1991) yang menyatakan bahwa pengalaman dalam menjalankan usaha merupakan prediktor terbaik bagi keberhasilan, terutama bila bisnis baru itu berkaitan dengan pengalaman sebelumnya $^{19}$. Kebutuhan akan pengalaman mengolah usaha semakin diperlukan dengan meningkatnya kompleksitas lingkungan (Sugianto, 2014) ${ }^{20}$.

Kemudian dari hasil uji statistik antara penggunaan informasi akuntansi dengan pengembangan usaha diperoleh nilai $t_{\text {hitung }}=4,684>t_{\text {tabel }}=2,026$ yang menunjukkan bahwa penggunaan informasi akuntansi berpengaruh terhadap pengembangan usaha pada pelaku UKM.

Hasil penelitian ini dapat ditinjau dari pendapat Holmes (1998) dalam Mustaqhfiroh (2016) yang menyatakan bahwa kekurangan informasi akuntansi dalam manajemen perusahaan dapat membahayakan perusahaan kecil. Kondisi keuangan yang memburuk dan kekurangan catatan akuntansi akan membatasi akses untuk memperoleh informasi yang diperlukan sehingga akan menyebabkan kegagalan perusahaan. Pendapat tersebut menggambarkan bahwa informasi akuntansi dapat mempengaruhi suatu wirausaha ataupun dalam mengembangkan wirausaha. Bila dilihat dari makna yang terkandung di dalam informasi akuntansi tersebut dapat diketahui bahwa informasi akuntansi dapat memberikan setiap kegiatan keuangan dari suatu usaha seperti keadaan keuangan usaha.

\section{Pengaruh Pengalaman Usaha Terhadap Pengembangan Usaha Pada} Pelaku UKM Melalui Penggunaan Informasi Akuntansi 
Dari hasil uji statistik diperoleh nilai pengaruh tidak langsung sebesar 0,626 lebih besar dari pengaruh langsung sebesar 0,432 yang menunjukkan bahwa pengalaman usaha secara tidak langsung berpengaruh terhadap pengembangan usaha pada pelaku UMKM melalui penggunaan informasi akuntansi.Pengalaman berusaha memperoleh banyak pembelajaran tentang informasi apa yang dibutuhkan dan digunakan dalam pengambilan keputusan. Manajemen perusahaan akan membutuhkan informasi yang lebih banyak akan disiapkan dan digunakan dalam pengambilan keputusan apabila tingkat kompleksitas usaha serta persaingan semakin ketat. Oleh karena itu Nicholls dan Holmes (1989) yang dikutip Fitriyah (2006) mengemukakan bahwa pengalaman dalam operasional berusaha atau lamanya perusahan beroperasi berdasarkan pada bisnis yang sudah dijalankan akan mengindikasikan kebutuhan akan informasi akuntansi sangat diperlukan.

Di sisi lain, ketidakmampuan menyediakan dan menggunakan informasi akuntansi merupakan salah satu kelemahan dari sisi manajemen. Kelemahan ini merupakan faktor utama yang mengakibatkan kegagalan UKM dalam mengembangkan usaha. Hal ini dapat dilihat dari pendapat Haron dan Bala (1994) dalam Fitriyah (2006) yang mengemukakan bahwa kemampuan untuk menyediakan dan menggunakan informasi akuntansi sangat tergantung pada kemampuan pemilik untuk menjalankan teknis akuntansi. Informasi akuntansi sangat bermanfaat bagi UKM, karena merupakan alat yang digunakan oleh pengguna informasi untuk pengambilan keputusan. Informasi akuntansi memiliki peranan yang sangat penting untuk meraih keberhasilan usaha, termasuk bagi usaha kecil (Megginson et al, 2000 dalam Pinasti 2007). Informasi akuntansi mempunyai peran penting untuk mencapai sebuah keberhasilan usaha sekaligus merupakan hasil akhir dari suatu proses akuntansi yang digunakan oleh berbagai pihak-pihak yang berkepentingan. Dengan adanya informasi-informasi tersebut, memungkinkan para pelaku usaha kecil menengah dapat mengidentifikasi dan memprediksi area-area permasalahan yang mungkin akan timbul dikemudian hari, kemudian mengambil tindakan koreksi tepat waktu.

\section{Pengaruh Pengetahuan Akuntansi Terhadap Pengembangan Usaha Pada Pelaku UKM Melalui Penggunaan Informasi Akuntansi}


Dari hasil uji statistik diperoleh nilai pengaruh tidak langsung sebesar 0,672 lebih besar dari pengaruh langsung sebesar 0,438 yang menunjukkan bahwa pengetahuan akuntansi secara tidak langsung berpengaruh terhadap pengembangan usaha pada pelaku UKM melalui penggunaan informasi akuntansi.

Pengetahuan akuntansi diartikan sebagai suatu persepsi jelas akan apa yang dipandang sebagai fakta, kebenaran, atau informasi mengenai proses pencatatan, pengelompokan, dan pengikthsaran kejadian-kejadian ekonomi dalam bentuk yang teratur dan logis dengan tujuan menyajikan informasi keuangan yang dibutuhkan untuk pengambilan keputusan. Menurut Abubakar. A dan Wibowo (2004) bahwa manfaat pengetahuan akuntansi bagi perusahaan diantaranya adalah mengetahui perkembangan atau maju mundurnya perusahaan, menjelaskan keadaan perusahaan sewaktu-waktu memerlukan kredit bank atau pihak lain dan dasar untuk menentukan kebijakan yang akan ditempuh.

Dari pendapat Abubakar dan Wibowo tersebut menunjukkan bahwa pengetahuan akuntansi yang dimiliki pelaku UKM dijadikan dasar untuk menggunakan informasi akuntansi untuk pengambilan keputusan terhadap kemajuan usaha yang dijalankannya yang diantaranya adalah mengembangkan usaha. Seorang wirausaha yang memiliki kemampuan yang baik tentang pengetahuan akuntansi akan lebih cenderung menggunakan informasi akuntansi untuk mengembangkan usaha. Pelaku UKM dapat mengetahui seberapa besar modal yang dimiliki untuk mengembangkan usahanya sehingga dengan demikian informasi akuntansi sangat penting bagi pelaku UKM.

\section{Kesimpulan}

1. Pengetahuan akuntansi secara parsial berpengaruh terhadap penggunaan informasi akuntansi dan Pengalaman usaha secara parsial tidakberpengaruh terhadap penggunaan informasi akuntansi.

3. Pengetahuan akuntansi dan pengalaman usaha secara simultan berpengaruh terhadap penggunaan informasi akuntansi.

4. Pengetahuan akuntansi secara tidak langsung berpengaruh terhadap pengembangan usaha pada pelaku UKM melalui penggunaan informasi akuntansi. 
Formaida Tambunan: Pengaruh Pengetahuan Akuntansi Dan Pengalaman |391

5. Pengalaman usaha secara tidak langsung berpengaruh terhadap pengembangan usaha pada pelaku UMKM melalui penggunaan informasi akuntansi.

\section{Saran}

1. Bagi Pelaku UKM

Untuk mengembangkan usaha yang sedang dijalankan diharapkan pelaku UKM dapat menggunakan informasi akuntansi sebagai alat pengambilan keputusan dengan mempelajari akuntansi karena melalui pengetahuan akuntansi, pelaku UKM dapat membuat perencanaan dan pengambilan keputusan dalam pengembangan usahanya.

2. Bagi Peneliti Selanjutnya

Penelitian ini dapat dikembangkan dengan menambah beberapa variabel yang dapat mempengaruhi pengembangan usaha.

\section{Endnote}

1 Tulus. Tambunan. Usaha Kecil dan Menengah di Indonesia. (Jakarta: Salemba Empat, 2002). h. 97

${ }^{2}$ Dwi Lestanti. Pengaruh Pengetahuan Akuntansi, Pengalaman Usaha, dan Motivasi Kerja Terhadap Persepsi Penggunaan Informasi Akuntansi Pada Pelaku UMKM di Boyolali. (Yogyakarta: Skripsi, Universitas negeri Yogyakarta, 2015) h. 102.

${ }^{3}$ Dinas Koperasi dan UMKM Kota Medan, Data Jumlah UKM di Kota Medan Tahun 2017. (Medan, 2017)

${ }^{4}$ Elsa Nanda Utami, Mulyaningsih dan Hendrati Dwi. Pengaruh Kompetensi Kewirausahaan Terhadap Kinerja UMKM (Studi Pada UMKM peserta program PUSPA 2016 yang diselenggarakan oleh Bank Indonesia). (eProceeding of Management : Vol.4, No.1 April 2017). h. 643.

${ }^{5}$ Dwi Lestanti. Pengaruh Pengetahuan Akuntansi, Pengalaman Usaha, dan Motivasi Kerja Terhadap Persepsi Penggunaan Informasi Akuntansi Pada Pelaku UMKM di Boyolali. (Yogyakarta: Skripsi, Universitas negeri Yogyakarta, 2015). h. 81 .

${ }^{6}$ Zaki Baridwan. Intermediate Accounting. Edisi Tujuh. (Yogyakarta: BPFE, 2000). h. 112. 
${ }^{7}$ Muhammad Arfan Ikhsan dan Ishak. Akuntansi Keprilakuan. (Jakarta: Salemba Empat). h.36.

${ }^{8}$ Tarmizi, Rosmiaty dan Ni Luh Sartika Bugawanti. Pengaruh Persepsi Pengusaha Kecil dan Menengah terhadap Penggunaan SAK ETAP di Kota Bandar Lampung. Jurnal Akuntansi dan Keuangan Vol 4 tahun 2013, No 2. h. 21 .

${ }^{9}$ Purwanti, Ira \& Hudiwinarsih, Gunasti, Persepsi Manajer Atas Informasi Akuntansi Keuangan Dan Pengaruhnya Pada Keberhasilan Mengelola Perusahaan Kecil Dan Menengah Di Surabaya. (The Indonesian Accounting Review, Volume 2, No. 1, January 2012, pages $11-24,2012)$ h.22.

${ }^{10}$ Sunaryanto, Studi Mengenai Orientasi Tenaga Penjual Pada Pelanggan Yang Mempengaruhi Kinerja Tenaga Penjual. (Semarang: Tesis Universitas Diponegoro, 2005). h. 114.

${ }^{11}$ Yayuk Widiyanti. Analisis Faktor-Faktor Yang Mempengaruhi Persepsi Pengushaa Kecil Dan Menengah Atas Penggunaan Informasi Akuntansi Keuangan. (Studi Pada Pengusaha Kecil dan Menengah di Sentra KerajinanTas Kain Kabupaten Kendal). (Semarang: Skripsi Akuntansi Universitas Negeri Semarang, 2013). h. 28.

12 Ibid. h. 29.

${ }^{13}$ A. Abubakar \& Wibowo. Akuntansi Untuk Bisnis: Usaha Kecil Dan. Menengah. (Jakarta: Grasindo, 2004), h.112

14 Destiana Setyaningrum, Adi Wiratno dan Sukirman, 2014. Pengaruh Pendidikan Pemilik, Pengetahuan Akuntansi Pemilik, Budaya Perusahaan, Dan Umur Usaha Terhadap Penggunaan Informasi Akuntansi Pada UKM Dengan Ketidakpastian Lingkungan Sebagai Variabel Pemoderasi (Studi Empiris Terhadap UKM Yang Menghasilkan Produk Unggulan Di Kabupaten Banyumas). Journal \& Proceeding Universitas Jenderal Sudirman, Vol. 4 No.1, 2014 h. 19-20.

15 Anoraga Pandji, Pengantar bisnis. Pengelolaan Bisnis Dalam Era Globalisasi. (Jakarta: Rieneka Cipta, 2007). h.95

${ }^{16}$ Harmaizar Z. Menggali Potensi Wirausaha. (Bekasi: Dian Anugerah Prakas, 2006). h. 85.

${ }^{17}$ Mustaqhfiroh. Faktor Penentu Penggunaan Informasi Akuntansi Pada Usaha Kecil dan Menengah Dengan Good Corporate Governance Sebagai Variabel Intervening. (Semarang: Skripsi S1, Universitas Negeri Semarang, 2016). h. 23. 
Formaida Tambunan: Pengaruh Pengetahuan Akuntansi Dan Pengalaman |393

18 Hadiah Fitriyah. Analisis Faktor-Faktor yang Mempengaruhi Penggunaan Informasi Akuntansi Pada Usaha. (Surabaya: Tesis Program Pasca Sarjana Universitas, 2006) Airlangga. h. 83.

Sugianto. "Pengaruh Pendidikan, Pengalaman Usaha, Dan Jenis Usaha Terhadap Penggunaan Informasi Akuntansi Pada Usaha Kecil Dan Menengah Yang Ada di Kecamatan Tanjungpinang Timur Kota Tanjung Pinang”, Makalah Fakultas Ekonomi Universitas Maritim Raja Ali Haji, Tanjung Pinang tahun 2014

${ }^{19}$ Benedicta Prihatin Dwi Riyanti. Kewirausahaan Dari Sudut Pandang Psikologi Kepribadian. (Jakarta : PT Grasindo, 2003). h.41.

${ }^{20}$ Sugianto, Pengaruh Pendidikan, Pengalaman Usaha, Dan Jenis Usaha Terhadap Penggunaan Informasi Akuntansi Pada Usaha Kecil Dan Menengah Yang Ada di Kecamatan Tanjungpinang Timur Kota Tanjung Pinang, Makalah Fakultas Ekonomi Universitas Maritim Raja Ali Haji, Tanjung Pinang, 2014. h. 23.

\section{DAFTAR PUSTAKA}

Tambunan, Tulus. 2002. Usaha Kecil dan Menengah di Indonesia.Jakarta: Salemba Empat.

Lestanti, Dwi. 2015. Pengaruh Pengetahuan Akuntansi, Pengalaman Usaha, dan Motivasi Kerja Terhadap Persepsi Penggunaan Informasi Akuntansi Pada Pelaku UMKM di Boyolali. Yogyakarta: Skripsi. Universitas negeri Yogyakarta.

Dinas Koperasi dan UMKM Kota Medan, Data Jumlah UKM di Kota Medan Tahun 2017. Medan. 2017.

Utami, Elsa Nanda \& Mulyaningsih, Hendrati Dwi. Pengaruh Kompetensi Kewirausahaan Terhadap Kinerja UMKM (Studi Pada UMKM peserta program PUSPA 2016 yang diselenggarakan oleh Bank Indonesia). eProceeding of Management : Vol.4, No.1 April 2017.

Baridwan, Zaki, 2000. Intermediate Accounting. Edisi Tujuh. Yogyakarta: BPFE.

Ikhsan, Arfan \& Ishak, Muhammad. 2005. Akuntansi Keprilakuan. Jakarta: Salemba Empat.

Tarmizi, Rosmiaty dan Ni Luh Sartika Bugawanti. 2013. Pengaruh Persepsi Pengusaha Kecil dan Menengah terhadap Penggunaan SAK ETAP di Kota Bandar Lampung. Jurnal Akuntansi dan Keuangan Vol 4, No 2. 
Purwanti, Ira \& Hudiwinarsih, Gunasti, Persepsi Manajer Atas Informasi Akuntansi Keuangan Dan Pengaruhnya Pada Keberhasilan Mengelola Perusahaan Kecil Dan Menengah Di Surabaya. The Indonesian Accounting Review, Volume 2, No. 1, January 2012, pages 11 - 24, 2012.

Sunaryanto, Studi Mengenai Orientasi Tenaga Penjual Pada Pelanggan Yang Mempengaruhi Kinerja Tenaga Penjual. (Semarang: Tesis Universitas Diponegoro, 2005.

Widiyanti, Yayuk. Analisis Faktor-Faktor Yang Mempengaruhi Persepsi Pengushaa Kecil Dan Menengah Atas Penggunaan Informasi Akuntansi Keuangan. (Studi Pada Pengusaha Kecil dan Menengah di Sentra KerajinanTas Kain Kabupaten Kendal). Semarang: Skripsi Akuntansi Universitas Negeri Semarang, 2013.

Abubakar, A., \& Wibowo. 2004. Akuntansi Untuk Bisnis: Usaha Kecil Dan. Menengah. Jakarta: Grasindo.

Setyaningrum, Destiana; Adi Wiratno dan Sukirman. 2014. Pengaruh Pendidikan Pemilik, Pengetahuan Akuntansi Pemilik, Budaya Perusahaan, Dan Umur Usaha Terhadap Penggunaan Informasi Akuntansi Pada UKM Dengan Ketidakpastian Lingkungan Sebagai Variabel Pemoderasi (Studi Empiris Terhadap UKM Yang Menghasilkan Produk Unggulan Di Kabupaten Banyumas). Journal \& Proceeding Universitas Jenderal Sudirman , Vol. 4 No.1.

Anoraga, Pandji. 2007. Pengantar bisnis. Pengelolaan Bisnis Dalam Era Globalisasi. Jakarta: Rieneka Cipta.

Harmaizar Z. 2006. Menggali Potensi Wirausaha. Bekasi: Dian Anugerah Prakas.

Mustaqhfiroh. 2016. Faktor Penentu Penggunaan Informasi Akuntansi Pada Usaha Kecil dan Menengah Dengan Good Corporate Governance Sebagai Variabel Intervening. Semarang: Skripsi S1, Universitas Negeri Semarang.

Fitriyah, Hadiah. 2006. Analisis Faktor-Faktor yang Mempengaruhi Penggunaan Informasi Akuntansi Pada Usaha. Surabaya: Tesis Program Pasca Sarjana Universitas.

Sugianto. 2014. Pengaruh Pendidikan, Pengalaman Usaha, Dan Jenis Usaha Terhadap Penggunaan Informasi Akuntansi Pada Usaha Kecil Dan Menengah Yang Ada di Kecamatan Tanjungpinang Timur Kota Tanjung Pinang. Tanjung Pinang: Makalah Fakultas Ekonomi Universitas Maritim Raja Ali Haji.

Riyanti, Benedicta Prihatin Dwi. 2003. Kewirausahaan Dari Sudut Pandang Psikologi Kepribadian. Jakarta : PT Grasindo. 